Journal An-Nafs: Kajian Penelitian Psikologi

http://ejournal.iai-tribakti.ac.id/index.php/psikologi

e-ISSN: 2549-6166

p-ISSN: 2528-0600

DOI: $10.33367 /$ psi.v5i2.1140

Submitted: $\quad$ Revised: Accepted: Published:

06-05-2020 02-06-2020 13-07-2020 01-12-2020

\title{
KARAKTERISTIK KEPRIBADIAN NARAPIDANA KASUS PEMBUNUHAN BERENCANA DITINJAU DARI MINNESOTA MULTIPHASIC PERSONALITY INVENTORY-2
}

\author{
${ }^{1}$ Rahel Gloria Natalia Abel, ${ }^{2}$ Setyani Alfinuha \\ ${ }^{1}$ rahel.abel20@gmail.com, ${ }^{2}$ setyanialfinuha@gmail.com \\ Universitas Surabaya
}

\begin{abstract}
Crime as premeditated murder is one of the main problems in Indonesia. The prevalence of murder cases tends to increase. Personality characteristics that play a role in the case of premeditated murder are unique. Prison convicts have varied and unique personality compared to people in general. A test uses to find out the personality traits that were needed to administer. Thus, the diagnosis and application of intervention were preciseness. The measuring instrument employed in this study was the Minnesota Multiphasic Personality Inventory-2 (MMPI-2). This study aims to determine the psychopathological indications of convicted murder cases in MMPI-2. The sampling technique used purposive sampling with one participant planning murder who was serving a prison sentence of 20 years. The result is participants had a psychopathological predisposition to schizophrenia (84 = very high), paranoia $(83=$ very high $)$, and hypomania $(81=$ very high $)$. A prisoner with this kind of psychopathological predisposition tended to feel insecure, lonely, anxious, and depressed but sometimes also felt happy or have excessive energy. The participant also avoided social relations and did not want to involve emotions deeply. The results of MMPI-2 showed that the characteristics of schizophrenia, paranoid, hypomania might encourage someone to commit sadistic behavior such as serial killings.
\end{abstract}

Keywords: Prisoner, premeditated murder, MMPI-2

\begin{abstract}
Abstrak
Kriminalitas seperti pembunuhan berencana merupakan salah satu masalah utama di Indonesia. Prevalensi kasus pembunuhan berencana cenderung mengalami peningkatan. Karakteristik kepribadian yang berperan dalam kasus pembunuhan berencana cukup unik. Narapidana kasus pembunuhan berencana memiliki kepribadian yang berbeda dan khas dibandingkan orang pada umumnya. Guna mengetahui kekhasan diperlukan tes agar diagnosa dan penerapan intervensi dapat diberikan dengan tepat. Alat ukur yang digunakan pada penelitian ini adalah Minnesota Multiphasic Personality Inventory-2 (MMPI-2). Tujuan dari penelitian ini adalah untuk mengetahui indikasi psikopatologis dari narapidana kasus pembunuhan berencana yang ditinjau dari MMPI-2. Teknik pengambilan sampel menggunakan purposive sampling dengan satu partisipan pembunuh berencana yang sedang menjalani hukuman penjara (vonis hukuman 20 tahun). Hasil penelitian menunjukkan bahwa partisipan memiliki kecenderungan psikopatologis schizophrenia $(84=$ very high $)$, paranoia $(83=$ very high $)$, dan hypomania $(81=$ very high $)$. Narapidana dengan tipe ini cenderung merasa tidak percaya diri, tidak aman, kesepian, cemas hingga depresi namun terkadang juga merasakan bahagia atau memiliki energi yang berlebihan. Partisipan juga menghindari relasi sosial dan tidak mau melibatkan emosi secara mendalam. Berdasarkan hasil MMPI-2 menunjukkan bahwa karakteristik
\end{abstract}


skizofrenia, paranoid, hipomania dapat mendorong seseorang untuk melakukan perilaku sadis seperti pembunuhan berencana.

Kata kunci: Narapidana, pembunuhan berencana, MMPI-2

\section{PENDAHULUAN}

Perilaku kriminal adalah kategori perilaku yang secara sosial, budaya, politik, dan ekonomi menyimpang dari aturan hukum yang ada (Helfgott, 2008). Aturan hukum di suatu daerah berbeda dengan yang lainnya sehingga identifikasi prilaku kriminalnya pun juga berbeda. Alasan seseorang melakukan tindak kriminal cukup beragam, mulai dari level makro hingga personal.

Terdapat empat teori seseorang melakukan tindakan kriminal. Pertama, societal/ macro level theory yaitu penyebab dari tindak kriminal didasarkan pada struktur sosial yang bermasalah. Adanya kesenjangan dalam status sosial ekonomi, kesulitan lapangan pekerjaan, kebencian pada ras tertentu, atau adanya konsep yang bermasalah mengenai gender. Kedua, community/ locality theory yaitu penyebab tindak kriminal didasarkan pada adanya situasi di lingkungan atau komunitas yang mendorongnya melakukan tindakan tersebut. Setiap area tertentu di suatu wilayah memiliki kondisi/situasi yang berpotensi meningkatkan atau menurunkan perilaku kriminal (Howitt, 2009).

Ketiga, group and socialisation influence theory yaitu penyebab tindak kriminal disebabkan karena adanya pengaruh dari teman atau keluarga. Lingkungan di sekitar dan pergaulan menentukan kemungkinan seseorang untuk melakukan tindak kriminal. Keempat, individual approaches yaitu penyebab tindak kriminal disebabkan adanya kondisi biologis maupun psikologis yang dimiliki setiap orang. Psikopatologis atau penyakit mental, tekanan mental, dan abnormalitas atau perilaku maladaptif dapat mendorong seseorang melakukan kejahatan tertentu (Cline, 2015). Keempat alasan seseorang melakukan tindakan kriminal tersebut biasanya saling memengaruhi dan tidak berdiri sendiri. Depresi, PTSD, gangguan psikotik, gangguan fungsi intelektual, dan penyalahgunaan narkoba umumnya menjadi faktor yang mendorong seseorang melakukan pembunuhan (Cartwright, 2001).

Salah satu bentuk perilaku kriminal adalah pembunuhan berencana. Pembunuhan merupakan perilaku individu atau kelompok yang berakibat hilangnya nyawa orang lain. Pembunuhan dapat dilatarbelakangi oleh berbagai faktor sehingga memutuskan melakukan pembunuhan (Dariyo, 2013). Pembunuhan berencana sesuai pasal $340 \mathrm{Kitab}$ Undang-Undang Hukum Pidana (KUHP) yaitu pembunuhan seperti pasal 338 KUHP namun dilakukan dengan perencanaan terlebih dulu. Adanya perencanaan yaitu antara 
Rahel Gloria Natalia Abel \& Setyani Alfinuha | Karakteristik Kepribadian

niat membunuh dengan pelaksanaannya terdapat waktu bagi pelaku dengan tenang memikirkan cara pembunuhan yang hendak dilakukan. Perbedaan antara pembunuhan yang direncanakan dan pembunuhan biasa adalah apabila pembunuhan biasa waktu pelaksanaan pembunuhan yang dimaksud pasal 338 KUHP dilakukan seketika pada waktu timbul niat sedangkan pembunuhan berencana pelaksanannya ditangguhkan setelah niat itu timbul guna mengatur rencana serta cara pembunuhan akan dilaksanakan (Grossman, 2009).

Kejahatan terhadap manusia (a crime against humanity) seperti pembunuhan merupakan tindakan yang tidak dapat dibenarkan oleh hukum. Pembunuhan merupakan perilaku yang sadis dan kejam. Pembunuhan berarti mencabut paksa nyawa orang lain dan memupus eksistensi hidup korbannya. Perilaku pembunuhan merupakan bentuk kekerasan yang sangat ekstrem. Pembunuhan dapat terjadi pada individu maupun anggota kelompok sosial manapun sehingga peristiwa ini menimbukan stres di kehidupan manusia (Krahe, 2005).

Perilaku pembunuhan merupakan salah satu tindak kriminal dalam KUHP disebut sebagai tindak pidana terhadap nyawa yang disebutkan pada Bab XIX dengan judul "kejahatan terhadap nyawa orang" dan diatur dalam pasal 338 hingga pasal 350. Keterbatasan kajian ilmiah terkait pembunuhan menjadikan fenomena pembunuhan sebagai blind spot di kehidupan masyarakat. Kondisi ini disebut blind spot sebab masyarakat mengalami kesulitan dalam melihat dengan lebih jelas dan akurat terkait fenomena yang sesungguhnya ada di tengah masyarakat (Grossman, 2009). Pemberitaan di media tentang pembunuhan juga semakin gencar mendapat perhatian dan menimbulkan kekhawatiran serta ketakutan (Wong \& Harraway, 2019). Maka dari itu, studi terhadap kasus pembunuhan sangat diperlukan guna mengungkap fakta-fakta yang belum diketahui (Grossman, 2009).

Pemahaman terhadap perilaku membunuh dapat membantu manusia untuk menghindarkan diri dari perilaku tersebut. Salah satu alternatif alat ukur yang dapat digunakan untuk melakukan profiling karakteristik individu dengan kecenderungan melakukan pembunuhan adalah alat ukur MMPI (Putra et al., 2016). Berbagai kasus pembunuhan di Indonesia pada kurun waktu beberapa tahun terakhir juga mengalami peningkatan (Yeni et al., 2017). Secara global, angka kasus pembunuhan juga meningkat (Rosenfeld, 2019). Peningkatan yang terjadi tidak hanya dari sisi kuantitas namun juga dari sisi kualitas di mana pelakunya tidak hanya semakin banyak melainkan juga semakin nekat dan sadis. Hasil penelitian sebelumnya tentang karakteristik pembunuh berencana menunjukkan bahwa profil pelaku pembunuhan berencana tidak dapat dilihat dari segi 
ciri-ciri fisik karena setiap pelaku memiliki ciri-ciri fisik yang berbeda. Profil pelaku juga tidak dapat dilihat dari demografis pelaku karena tidak ada yang sama antara pelaku satu dengan pelaku yang lainnya. Kendati demikian, latar belakang ekonomi dan pendidikan yang rendah bisa menjadi pemicu seseorang menjadi pelaku pembunuhan (Yeni et al., 2017).

Perilaku pembunuhan berencana juga dapat dipengaruhi oleh kondisi psikopatologis (Howitt, 2009). Salah satunya adalah karakteristik kepribabdian psikopatologi yang memiliki kecenderungan melakukan pembunuhan (Putra et al., 2016). Sebanyak 759 narapidana yang ditahan memiliki riwayat kontak dengan layanan kesehatan mental pada tahun sebelum pelanggaran dilakukan dan disertai dengan laporan psikiatrik. Secara umum, pola kasus pembunuhan diasosiasikan dengan satu atau lebih kesehatan mental (Abreu Minero et al., 2018).

Salah satu pendekatan yang dapat digunakan untuk melakukan profil psikologis pelaku pembunuhan yaitu dengan menganalisis gangguan mental yang diderita. Hal ini penting dilakukan karena investigator pembunuhan memerlukan data tentang apakah kasus tertentu termasuk perilaku yang rentan terhadap pelaku dengan penyakit mental (Häkkänen, 2010). Psikopatologis seperti gangguan mental dan gangguan afektif dapat mendorong seseorang untuk melakukan pembunuhan (Abreu Minero et al., 2017).

Salah satu alat ukur yang sering digunakan untuk melihat karakteristik kepribadian adalah Minnesota Multiphasic Personality Inventory (MMPI). Alat ukur ini digunakan secara luas untuk mengetahui kepriadian secara klinis. Selain itu berbagai studi menunjukkan validitas dan penggunakan MMPI dalam asesmen kasus-kasus klinis. MMPI merupakan tes kepribadian objektif yang paling banyak digunakan dan dipelajari. Pada tahun 1940-an, McKinley dan Hathaway di Universiry of Minnesota Amerika Serikat awalnya menjadikan MMPI sebagai metode pengukuran objektif perilaku abnormal (Butcher, 2000).

Dengan demikian, tujuan utama dari MMPI adalah pengukuran untuk diagnosis dan klasifikasi psikiatris dan bukan untuk pengukuran kepribadian umum (Butcher, 2000). Penelitian sebelumnya juga menggunakan MMPI sebagai alat untuk mengetahui kecenderungan psikopatologis narapidana pembunuhan. Penelitian tersebut menunjukkan bahwa dari hasil tes MMPI, diketahui sebagian besar pembunuh memiliki indikasi gangguan psikopatologis (Culhane et al., 2014). MMPI juga dapat digunakan untuk melihat kecenderungan psikolapotogi seseorang (Putra et al., 2016).

MMPI berisi 10 skala klinis untuk mengukur jenis perilaku abnormal utama dan empat skala validitas untuk mengukur sikap pengambilan tes partisipan. MMPI terdiri dari 
Rahel Gloria Natalia Abel \& Setyani Alfinuha | Karakteristik Kepribadian

383 pertanyaan. Pada setiap pertanyaan, partisipan memberikan jawaban 'ya' atau 'tidak' (Butcher et al., 1989). Sifat penilaian diagnostik yang sensitif terhadap waktu maka harus sering membuat keputusan mengenai diagnosis berdasarkan pengamatan gejala seseorang yang muncul. Mengingat kesulitan tugas diagnostik, instrumen psikologis sering digunakan untuk mendapatkan informasi tentang individu yang tidak mudah terlihat selama wawancara awal.

Ada badan besar penelitian sebelumnya yang menguji kemampuan skor skala pada Minnesota Multiphasic Personality Inventory (Hathaway \& McKinley, 1943) dan Minnesota Multiphasic Personality Inventory-2 (Butcher et al., 1989) untuk membantu dalam diagnosis banding gangguan psikotik dan depresi, termasuk skizofrenia dan gangguan depresi mayor. Skala MMPI awalnya dikembangkan untuk membedakan antara berbagai bentuk psikopatologi (Hathaway \& McKinley, 1943), dengan cepat diakui bahwa kekuatan sebenarnya dari skala ini adalah dalam korelasi empiris yang dapat dibangun.

Penting mengidentifikasi indikasi psikopatologis pada pelaku pembunuhan (Masykur \& Subandi, 2018) maka dari itu penelitian ini berupaya mengungkap indikasi psikopatologis dari pelaku pembunuhan berencana. Keunikan dari penelitian ini adalah partisipan yang terlibat melakukan pembunuhan berencana yang sadis disertai dengan perampasan dan pemerkosaan. Keunikan tindakan pembunuhan berencana yang dilakukan oleh partisipan penelitian menjadi menarik untuk diketahui lebih dalam khususnya terkait indikasi psikopatologis yang mendorong perilaku kriminal. Penelitian ini juga berupaya mengungkap tindak pembunuhan baik dari sudut pandang teoritis maupun sudut pandang pelaku. Fenomena tersebut menarik untuk diungkap lebih jauh karena sifatnya yang unik. Kondisi ini disebut unik karena angka kasusnya yang relatif terbatas namun memiliki kecenderungan peningkatan di tengah masyarakat.

Berdasarkan pemaparan tersebut didapatkan gambaran bahwa indikasi gangguan psikologis juga menjadi salah satu faktor yang mendorong seseorang melakukan pembunuhan berencana khususnya yang bersifat sadis dan disertai pembunuhan serta pemerkosaan. Misalnya individu yang memiliki karakteristik kepribadian psikopati cenderung melakukan kekerasan bahkan membunuhan secara sadis (Putra et al., 2016). Maka dari itu kajian tentang gangguan psikologis narapidana kasus pembunuhan penting dilakukan dalam membuat profil psikologis sehingga dapat memetakkan potensi kejahatan yang dilakukan seseorang. Salah satu alat tes psikologi yang digunakan untuk mengetahui indikasi gangguan psikologis yaitu Minnesota Multiphasic Personality Inventory-2 (MMPI-2). Penelitian ini mengungkap indikasi psikopatologis narapidana pembunuhan berencana berdasarkan MMPI-2. 


\section{METODE}

Jenis penelitian ini adalah studi kasus kualitatif dengan satu orang partisipan. Pemilihan partisipan menggunakan purposive sampling yaitu peneliti memilih partisipan sesuai dengan tujuan tertentu. Kriteria yang ditetapkan dalam pemilihan partisipan adalah narapidana yang telah dijatuhi pasal 340 KUHP (pembunuhan berencana) dan sedang menjalani masa hukuman di lapas X. Partisipan dipilih karena jumlah pembunuhan khususnya pembunuhan berencana dari tahun ke tahun cenderung mengalami peningkatan (Yeni et al., 2017). Partisipan juga melakukan pembunuhan berencana yang disertai dengan perampasan dan pemerkosaan. Tindakan pembunuhan disertai dengan perampasan serta pemerkosaan merupakan tindakan sadis dan memiliki karakteristik yang khas (Chopin et al., 2020). Pengambilan data menggunakan data utama MMPI-2. Penggunaan MMPI-2 dilakukan untuk mengetahui indikasi psikopatologis yang dimiliki partisipan sebagai sumber data primer. Selain MMPI-2, penelitian ini juga menggunakan sumber data sekunder berupa observasi, wawancara, dan tes grafis terhadap partisipan sebagai penunjang hasil penelitian. Data yang didapat dianalisis secara kualitatif dengan teknik deskriptif.

\section{PAPARAN HASIL}

Pada penelitian ini, partisipan bernama Yudi (nama samaran) sedang menjalani masa hukuman dengan vonis 20 tahun atas kasus pembunuhan berencana yang dilakukan terhadap seorang perempuan berusia 23 tahun. Pembunuhan yang dilakukan Yudi disertai dengan perampasan dan pemerkosaan terhadap mayat korban. Motif pembunuhan berencana yang Yudi lakukan adalah ingin menguasai harta benda dan menyetubuhi korban.

Penelitian secara konsisten menunjukkan bahwa rata-rata individu yang melakukan satu atau lebih kasus pembunuhan kemungkinan besar memiliki catatan kriminal (Trojan \& Salfati, 2011). Berbeda dengan penelitian tersebut, kasus ini merupakan kasus pertama yang dilakukan Yudi dalam catatan kriminalnya. Yudi belum pernah melakukan tes kepribadian sebelumnya sehingga tidak diketahui secara pasti penyebab terbentuknya perilaku kriminal secara pribadi yang melatarbelakangi tindakan Yudi. Berikut ini merupakan identitas diri dari Yudi. 
Rahel Gloria Natalia Abel \& Setyani Alfinuha | Karakteristik Kepribadian

Tabel 1. Identitas Partisipan

\begin{tabular}{|l|l|}
\hline Nama & $:$ Yudi (nama samaran) \\
\hline Jenis Kelamin & $:$ Laki-laki \\
\hline Tempat/Tanggal Lahir & $:$ Sidoarjo, 15 Januari 1988 \\
\hline Usia & $:$ 32 tahun \\
\hline Alamat & $:$ Surabaya \\
\hline Pendidikan terakhir & $:$ S1 \\
\hline Pekerjaan & $:$ Pengepul rongsokan \\
\hline Suku Bangsa & $:$ Jawa Timur \\
\hline Latar Belakang Budaya & $:$ Jawa Timur \\
\hline Urutan dalam Keluarga & $:$ Anak ke-1 dari 2 bersaudara \\
\hline Status Pernikahan & $:$ Menikah \\
\hline Status Kriminal & $\begin{array}{l}: \text { Ditahan mulai tanggal 16/11/2013 dengan masa kurungan } 20 \\
\text { tahun penjara }\end{array}$ \\
\hline
\end{tabular}

Tabel 2. Hasil Pemeriksaan MMPI-2 Komposisi Standar Validitas dan Profil Skala Klinis

\begin{tabular}{|l|c|c|c|}
\hline \multicolumn{1}{|c|}{ Scale } & Raw Score & T Score & Klasifikasi \\
\hline VRIN & 13 & 80 & \\
\hline TRIN & 8 & $57 \mathrm{~F}$ & \\
\hline L Scale & 2 & 101 & \\
\hline F Scale & 22 & 92 & \\
\hline Fb Scale & 12 & 99 & \\
\hline Fp Scale & 8 & 43 & \\
\hline K Scale & 9 & 37 & \\
\hline S Scale & 13 & 36 & \\
\hline Scale 1 - Hypochondriasis (Hs) & 16 & 59 & Rata-rata \\
\hline Scale 2 - Depression (D) & 18 & 50 & Rata-rata \\
\hline Scale 3 - Hysteria (Hy) & 22 & 52 & Rata-rata \\
\hline Scale 4 - Psychopatic Deviate (Pd) & 29 & 64 & Cukup tinggi \\
\hline Scale 5 - Masculinity - Feminity (Male) & 29 & 56 & Cukup tinggi \\
\hline Scale 6 - Paranoia (Pa) & 19 & 83 & Sangat tinggi \\
\hline Scale 7 - Psychasthenia (Pt) & 37 & 72 & Tinggi \\
\hline Scale 8 - Schizophrenia (Sc) & 46 & 84 & Sangat tinggi \\
\hline Scale 9 - Hypomania (Ma) & 31 & 81 & Tinggi \\
\hline Scale 0 - Social Introversion (Si) & 29 & 55 & Rata-rata \\
\hline
\end{tabular}

Berdasarkan tabel 2 diketahui bahwa scale yang mendapatkan kategori sangat tinggi ( $\mathrm{T}>65)$ adalah scale 8 (schizophrenia), scale 6 (paranoia), dan scale 9 (hypomania). Hal ini menunjukkan bahwa partisipan memiliki indikasi gangguan psikologis schizophrenia, paranoia, dan hypomania. Nilai tertinggi adalah schizophrenia dengan nilai 84 (scale 8). Ketika nilai pada scale ini melebihi 70, partisipan dapat dikatakan memiliki perilaku psikotik. Individu dengan psikotik biasanya memiliki pola berpikir yang aneh, halusinasi, delusi dan kurang bisa dimengerti. Selisih satu dari nilai schizophrenia, nilai tertinggi kedua adalah paranoia dengan nilai 83. Seseorang dengan nilai paranoid tinggi biasanya tidak hanya memiliki kecurigaan yang berlebihan melainkan sudah berkembang menjadi delusi dan pemikiran tidak rasional yang jauh dari realitas yang berisikan ketakutan. Scale ketiga yang juga memiliki nilai tinggi adalah hypomania. Berdasarkan 
Rahel Gloria Natalia Abel \& Setyani Alfinuha | Karakteristik Kepribadian

tabel diatas, partisipan memiliki nilai hypomania sebesar 81. Hypomania merupakan gangguan suasana hati yang dapat membuat seseorang lebih aktif dan bersemangat dibandingkan biasanya namun kemudian mendadak murung seperti sedang mengalami depresi. Hypomania merupakan salah satu ciri gangguan bipolar.

Grafik 1. Validitas dan Profil Skala Klinis MMPI-2

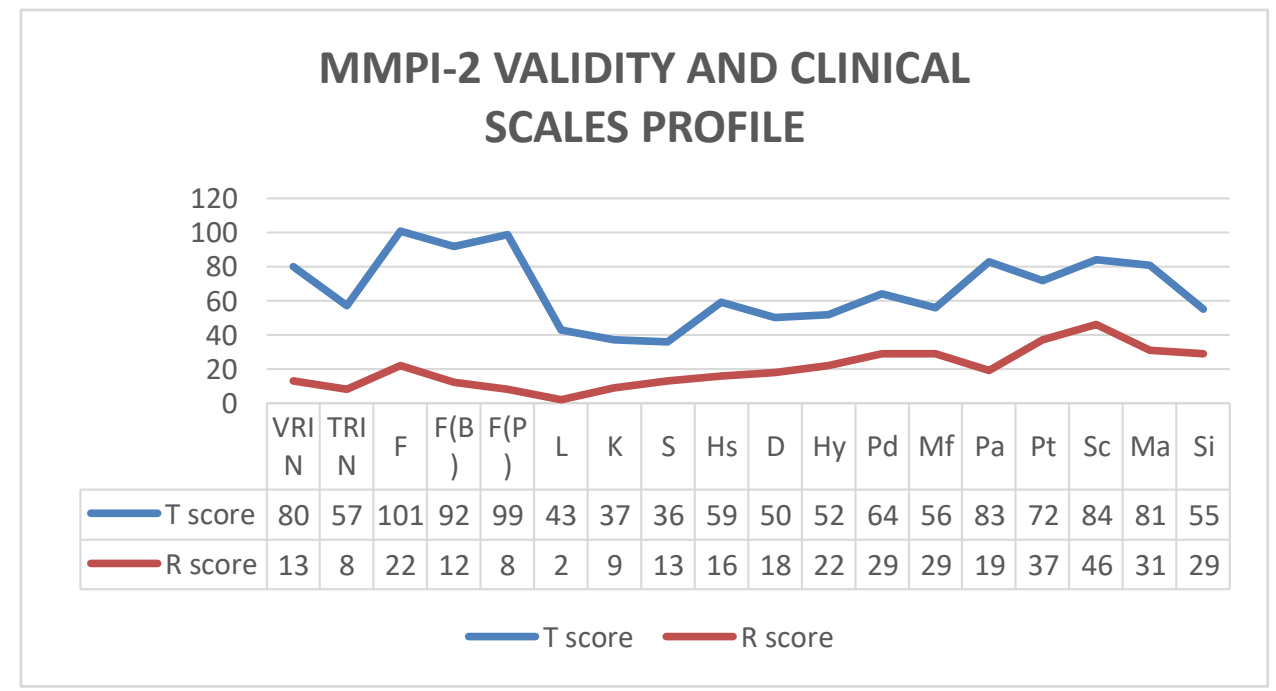

Tabel 3. Komposisi dari Subskala Harris-Lingoes

\begin{tabular}{|l|c|c|}
\hline \multicolumn{1}{|c|}{ Scale } & R. Scale 6 - Paranoia (Pa) & T. Score \\
\hline \multicolumn{2}{|c|}{ Scale 8 - Schizophrenia (Sc) } \\
\hline Persecutory ideas (Pa1) & $\mathbf{1 1}$ & $\mathbf{1 0 6}$ \\
\hline Poignancy (Pa2) & 2 & 52 \\
\hline Naivete (Pa3) & 7 & 58 \\
\hline \multicolumn{2}{|c|}{$\mathbf{6}$} & 68 \\
\hline Social Alienation (Sc1) & 6 & $\mathbf{9 8}$ \\
\hline Emotional Alienation (Sc2) & $\mathbf{1 1}$ & 78 \\
\hline Lack of Ego Mastery, Cognitive (Sc3) & $\mathbf{9 8}$ \\
\hline Lack of Ego Mastery, Conative (Sc4) & 8 & 89 \\
\hline Lack of Ego Mastery, Defective Inhibition (Sc5) & 81 \\
\hline Bizarre Sensory, Experiences (Sc6) & 5 & 60 \\
\hline \multicolumn{2}{|c|}{ Scale 9- Hypomania (Ma) } \\
\hline Amorality (Ma1) Hychomotor Acceleration (Ma2) & $\mathbf{1 0}$ & $\mathbf{7 3}$ \\
\hline Psychom & 2 & 41 \\
\hline Imperturbility (Ma3) & 5 & 56 \\
\hline Ego Inflation (Ma4) &
\end{tabular}

Berdasarkan tabel 3 diketahui bahwa pada sub-scale tertinggi pada scale paranoia adalah persecutory. Individu dengan sub-scale persecutory yang tinggi umumnya menganggap dunia sebagai ancaman, merasa orang lain tidak memahaminya dan salah paham kepadanya. Individu dengan karakteristik ini cenderung merasa curiga dan tidak 
Rahel Gloria Natalia Abel \& Setyani Alfinuha | Karakteristik Kepribadian

percaya kepada orang lain serta sering menyalahkan orang lain atas masalah yang menimpanya.

Sub-scale tertinggi pada scale schizophrenia adalah emotional alienation dan lack of ego mastery conative yang keduanya memiliki nilai T yang sama. Individu dengan sub-scale emotional alienation yang tinggi umumnya merasa depresi dan putus asa hingga berharap dirinya sudah mati. Individu dengan emotional alienation juga bersikap apatis terhadap aspek emosional dalam kehidupan sehari-hari. Kendati demikian, dibalik depresi dan apatis yang dialami, individu dengan emotional alienation memiliki kebutuhan sadistik dan/ disertai masokis dalam kehidupan seksualnya.

Individu yang memiliki sub-scale lack of ego mastery conative tinggi umumnya merasa bahwa hidupnya penuh dengan ketegangan yang menyebabkan mereka depresi dan mengalami keputusasaan. Individu dengan lack of ego mastery mengalami kesulitan dalam mengatasi masalah sehari-hari dan memiliki kekhawatiran yang berlebihan. Ketika menghadapi stres, individu tersebut cenderung mengatasinya dengan menarik diri ke dalam fantasi dan banyak melamun. Tidak jarang mereka akan berpikir untuk mengakhiri hidupnya.

Sub-scale tertinggi pada scale hypomania adalah sub-scale psychomotor acceleration. Individu dengan sub-scale psychomotor acceleration yang tinggi memiliki kecenderungan melakukan aktivitas eksesif yang kurang bertujuan, merasa tegang dan gelisah, merasa senang dan gembira tanpa alasan, cepat bosan dan mencari resiko, kesenangan atau bahaya sebagai cara untuk mengatasi kebosanannya. Selain itu memiliki impuls atau dorongan untuk melakukan sesuatu yang berbahaya dan mengagetkan. Hasil MMPI-2 juga sejalan dengan hasil wawancara, observasi, dan tes grafis yang telah dilakukan.

\section{PEMBAHASAN}

Terdapat empat faktor yang mendorong seseorang berperilaku kriminal yaitu struktur sosial yang bermasalah, situasi lingkungan atau komunitas yang mendukung perilaku pelanggaran, pengaruh teman atau keluarga, serta karakteristik individu seseorang (Howitt, 2009). Pada penelitian ini akan dibahas faktor yang mendorong perilaku kriminal berupa pembunuhan berencana yang disertai dengan perampasan dan pemerkosaan ditinjau dari karakteristik individu khususnya indikasi psikopatologis yang dimiliki. Psikopatologis atau penyakit mental, tekanan mental, dan abnormalitas atau perilaku maladaptif dapat mendorong seseorang melakukan kejahatan tertentu. Salah satu penelitian menunjukkan bahwa sejumlah narapidana yang ditahan memiliki 
riwayat kontak dengan layanan kesehatan mental sebelum melakukan pelanggaran (Abreu Minero et al., 2018).

Secara umum, pola kasus pembunuhan diasosiasikan dengan satu atau lebih gangguan kesehatan mental. Pola tempat kejadian perkara (TKP) berbeda juga menunjukkan latar belakang pelaku yang berbeda (Abraham, 2010). Kendati demikian, diantara perbedaan latar belakang pelaku terdapat persamaan yaitu adanya gangguan psikologis yang belum tuntas (Abreu Minero et al., 2017). Sesuai dengan kondisi partisipan yang terindikasi mengalami beberapa psikopatologis.

Hasil penelitian sebelumnya menunjukkan bahwa pelaku pembunuhan dengan dan tanpa gangguan mental berbeda satu sama lain dalam hal pelanggaran, karakteristik demografis, dan latar belakang (Oram et al., 2013). Contohnya, pelaku dengan gangguan mental cenderung kurang memiliki orang asing sebagai korban, lebih cenderung tua, dan memiliki latar belakang yang lebih bermasalah dibanding pelaku tanpa penyakit mental (Häkkänen, 2010). Berbeda dengan penelitian Häkkänen (2010), hasil penelitian ini menunjukkan bahwa partisipan melakukan pembunuhan terhadap orang yang lebih muda. Kendati demikian, terdapat data yang mendukung penelitian (Häkkänen, 2010) yaitu korban merupakan orang asing dan partisipan memiliki latar belakang yang lebih bermasalah (Ioannou et al., 2015).

Berdasarkan hasil analisis MMPI-2 yang dilakukan, didapatkan indikasi psikopatologis partisipan yaitu schizophrenia, paranoia, dan hypomania. Hasil ini juga didukung dengan tes grafis yang dilakukan terhadap partisipan. Kondisi ini dapat menjadi acuan dalam pembuatan profil psikologis pelaku pembunuhan. Salah satu pendekatan yang dapat digunakan untuk melakukan profil psikologis pelaku pembunuhan yaitu dengan menganalisis gangguan mental yang diderita. Hal ini penting dilakukan karena investigator pembunuhan memerlukan data tentang keterkaitan kasus tertentu terhadap perilaku yang rentan terhadap pelaku dengan penyakit mental (Häkkänen, 2010).

Partisipan memiliki nilai tertinggi pada indikasi schizophrenia. Hal ini menunjukkan bahwa partisipan memiliki indikasi perilaku psikotik yang biasanya berpola pikir yang aneh, halusinasi, delusi dan kurang bisa dimengerti. Sub-scale tertinggi pada scale schizophrenia adalah emotional alienation dan lack of ego mastery conative. Partisipan memiliki indikasi sub-scale emotional alienation yang tinggi umumnya merasa depresi dan putus asa hingga berharap dirinya sudah mati. Partisipan juga bersikap apatis terhadap aspek emosional dalam kehidupan sehari-hari. Kendati demikian, dibalik depresi 
Rahel Gloria Natalia Abel \& Setyani Alfinuha | Karakteristik Kepribadian

dan apatis yang dialami, partisipan juga memiliki kebutuhan sadistik dan/ disertai masokis dalam kehidupan seksualnya.

Depresi menjadi salah satu faktor yang mendorong seseorang melakukan kejahatan seperti pembunuhan (Abreu Minero et al., 2018). Dorongan seksualitas dapat menjadi faktor pendorong seseorang melakukan pembunuhan berencana (Knight, 2007). Pada diri partisipan, selain indikasi psikopatologis juga terdapat dorongan seksual dan kebutuhan melakukan perilaku sadistik (Sturup, 2018). Hal ini menjadi salah satu faktor yang mendorong partisipan melakukan pembunuhan berencana terhadap korban.

Sub-scale kedua yang memiliki nilai yang sama tinggi adalah lack of ego mastery conative. Partisipan dengan karakteristik ini umumnya merasa bahwa hidupnya penuh dengan ketegangan yang menyebabkan depresi dan mengalami keputusasaan. Partisipan juga kesulitan mengatasi masalah sehari-hari dan memiliki kekhawatiran yang berlebihan. Saat menghadapi stres, partisipan cenderung mengatasinya dengan menarik diri ke dalam fantasi dan banyak melamun. Tidak jarang partisipan akan berpikir untuk mengakhiri hidupnya.

Secara spesifik, indikasi skizofrenia dan psikosis dikaitkan untuk menganalisis kasus pembunuhan (Hughes et al., 2012). Seseorang yang menderita skizofrenia erat kaitannya dengan gejala delusi yang memungkinkan melakukan pembunuhan. Selain itu cara melakukan kejahatan oleh penyandang skizofrenia sebagian besar menggunakan senjata tajam (Abreu Minero et al., 2017). Hal ini karena adanya individu dengan kecenderungan skizofrenia lebih mungkin untuk membawa senjata dengan mudah (Meehan et al., 2006) sebagai respons terhadap pemikiran paranoid (De Zulueta, 2006). Lebih lanjut, ulasan terbaru menggunakan senjata tajam sebagai metode pembunuhan yang digunakan oleh individu dengan penyakit mental (Abreu Minero et al., 2018). Sesuai dengan penjelasan tersebut, partisipan juga memiliki kecenderungan skizofrenia dan paranoid yang mendorongnya melakukan pembunuhan berencana. Hanya saja alat yang digunakan bukan senjata tajam melainkan benda tumpul.

Nilai tertinggi kedua yang dimiliki partisipan adalah paranoia. Hal ini mengindikasikan partisipan memiliki kecurigaan yang berlebihan hingga berkembang menjadi delusi dan pemikiran tidak rasional dan jauh dari realitas yang berisikan ketakutan. Sub-scale tertinggi pada scale paranoia adalah persecutory. Partisipan umumnya menganggap dunia sebagai ancaman, merasa orang lain tidak memahaminya dan salah paham terhadapnya. Partisipan juga cenderung mudah merasa curiga dan tidak percaya kepada orang lain serta sering menyalahkan orang lain atas masalah yang menimpanya. Abreu Minero, et al. (2018) menyatakan bahwa paranoia atau paranoid 
merupakan dampak dari skizofrenia yang mengakibatkan seseorang bersikap selalu waspada dan berpotensi mendorong melakukan pembunuhan berencana terhadap orangorang yang dirasa mengancam dirinya .

Nilai tertinggi berikutnya yaitu hypomania yang mengindikasikan gangguan suasana hati dan dapat membuat partisipan lebih aktif dan bersemangat dibandingkan biasanya namun kemudian mendadak murung seperti sedang mengalami depresi. Kondisi hypomania ini merupakan salah satu ciri gangguan bipolar. Abreu Minero, et al. (2018) menjelaskan bahwa salah satu gangguan yang mendorong melakukan pembunuhan adalah bipolar. Sub-scale tertinggi pada scale hypomania yaitu psychomotor acceleration. Hal ini mengindikasikan kecenderungan partisipan melakukan aktivitas eksesif yang kurang bertujuan, merasa tegang dan gelisah, merasa senang dan gembira tanpa alasan, cepat bosan dan mencari resiko, kesenangan atau bahaya sebagai cara untuk mengatasi kebosanannya. Selain itu memiliki dorongan untuk melakukan sesuatu yang berbahaya dan mengagetkan.

Selain melakukan pembunuhan berencana, partisipan juga melakukan perampasan serta pemerkosaan. Pembunuhan merupakan manifestasi dari perilaku agresif seseorang terhadap orang lain. Perilaku agresif merupakan tindakan melukai atau menyakiti seseorang baik secara fisik maupun psikologis yang berakibat merugikan atau berbahaya bagi orang lain (Alifah, 2015). Knight (2007) dalam penelitiannya menjelaskan bahwa dorongan seksual bisa menjadi salah satu faktor yang memotivasi untuk melakukan pembunuhan. Selain dorongan agresi, dorongan seksual juga menjadi salah satu faktor yang melatarbelakangi pembunuhan berencana. Tindakan pembunuhan disertai dengan perampasan serta pemerkosaan merupakan tindakan sadis. Tempat kejadian perkara pembunuhan yang disertai pemerkosaan cenderung dilakukan di tempat yang dikenali oleh pelaku. Hal ini dikarenakan pelaku lebih merasa aman dan leluasa melakukan aksi kejahatannya (Chopin et al., 2020). Selain itu, karakteristik pembunuh berencana yang sadis biasanya dangkal secara emosional dan cenderung menikmati proses menyakiti atau membunuh orang lain.

Berdasarkan hasil analisis MMPI-2 menunjukkan bahwa partisipan mengalami indikasi psikolapotogis. Abreu Minero, et al. (2018) dalam penelitiannya menunjukkan bahwa psikopatologis seperti gangguan mental dan gangguan afektif dapat mendorong seseorang untuk melakukan pembunuhan. Selain karakteristik psikopatologis, Abreu Minero, et al. (2018) menjelaskan penyebab pembunuhan lain yang umum pada laki-laki yaitu gangguan kepribadian seperti bipolar, penyalahgunaan alkohol dan narkoba. Hasil studi menunjukkan bahwa gangguan kepribadian menjadi prediktor utama dalam 
Rahel Gloria Natalia Abel \& Setyani Alfinuha | Karakteristik Kepribadian

melakukan kejahatan. Gangguan kepribadian juga dapat mendorong seseorang melakukan pembunuhan (Declercq \& Audenaert, 2011).

Peningkatan studi yang berfokus pada manifestasi psikopatologis terhadap kasus spesifik (Steury \& Choinski, 1995) seperti pembunuhan menunjukkan bahwa jumlah kasus kejahatan dapat dipengaruhi oleh kondisi psikopatologis pelaku (Krakowski et al., 1986). Terkait dengan ancaman yang diberikan pada korban, pembunuh berencana ini biasanya digunakan untuk menutupi sisi lemah dalam dirinya. Pelaku pembunuhan berencana menjadikan korban sebagai objek agresi destruktifnya. Agresi destruktif yaitu berlakunya kembali penghinaan atau kekerasan di masa lalu yang mengakibatkan korban menjadi wakil simbolis dari penyiksaan pelaku di masa lalu (Knight, 2007).

Berbagai penelitian terdahulu menyebutkan berbagai latar belakang karakteristik yang berbeda pada pelaku pembunuhan. Kendati demikian, perbedaan karakteristik kepribadian tersebut memiliki persamaan yaitu adanya psikopatologis. Penyakit mental seperti skizofrenia, depresi, dan bipolar dapat mendorong seseorang melakukan pembunuhan berencana. Data pembunuhan yang didapat dari National Confidental Inquiry into Suicide and Homicide menunjukkan bahwa pelaku pembunuhan atau bunuh diri umumnya dilakukan oleh orang-orang dengan penyakit mental (Abreu Minero et al., 2018).

\section{SIMPULAN}

Terdapat beberapa indikasi psikopatologis yang mendorong partisipan melakukan pembunuhan berencana. Indikasi psikopatologis membuat partisipan merasa tidak percaya diri dan dibelenggu rasa curiga yang berlebihan, merasa depresi dan putus asa. Partisipan menghindari relasi sosial dan tidak mau melibatkan emosi secara mendalam. Saat menghadapi stres, partisipan mengatasinya dengan menarik diri ke dalam fantasi dan banyak melamun. Dibalik depresi dan keputusasaannya, partisipan memiliki sisi sadistik dan atau yang disertai masokis dalam kehidupan seksualnya. Berdasarkan hasil penelitian sebelumnya bahwa psikopatologis seperti skizofrenia, depresi, dan bipolar menjadi faktor yang dapat mendorong seseorang melakukan pembunuhan berenacana. Hal ini sesuai dengan kondisi partisipan yang memiliki ketiga indikasi tersebut.

Selain itu adanya dorongan agresi dan seksual yang menonjol juga turut mendorong partisipan melakukan pembunuhan yang disertai dengan pemerkosaan. Cara membunuh cukup sadis mendukung penelitian sebelumnya. Penelitian ini bersifat studi kasus dengan partisipan satu orang yang kurang dapat berlaku secara umum. Kendati demikian, hasil penelitian ini dapat memberikan profil atau gambaran pelaku 
Rahel Gloria Natalia Abel \& Setyani Alfinuha | Karakteristik Kepribadian

pembunuhan. Gangguan psikopatologis dapat mendorong seseorang melakukan kejahatan khususnya pembunuhan. Hasil penelitian ini juga dapat membantu profiler dalam mengidentifikasi pelaku pembunuhan atau indikasi kejahatan. Hal yang perlu dikembangkan dari penelitian ini adalah jumlah partisipan yang terbatas. Peneliti berikutnya disarankan untuk menambah jumlah partisipan serta variasi kejahatan yang dilakukan. Selain itu, peneliti berikutnya diharapkan juga menguraikan aspek-aspek pengukuran MMPI sehingga didapatkan dinamika yang lengkap terkait pelaku pembunuhan berencana.

\section{DAFTAR PUSTAKA}

Abraham, J. (2010). Mempertanyakan Pemrofilan Kriminal sebagai Sebuah Ilmu Psikologis. Psikobuana, 1(1), 13-28.

Abreu Minero, V., Barker, E., \& Bedford, R. (2017). Method of homicide and severe mental illness: A systematic review. Aggression and Violent Behavior, 37, 52-62. https://doi.org/10.1016/j.avb.2017.09.007

Abreu Minero, V., Dickson, H., Barker, E., Flynn, S., Ibrahim, S., \& Shaw, J. (2018). The patterns of homicide offence characteristics and their associations with offender psychopathology. Journal of Investigative Psychology and Offender Profiling, 15(3), 304-318. https://doi.org/10.1002/jip.1514

Alifah, A. M. (2015). Dinamika Psikologis Narapidana Anak Pelaku Pembunuhan, Naskah Publikasi. Universitas Surakarta.

Butcher, J. N. (2000). Basic Sources on the MMPI-2. University of Minnesota Press.

Butcher, J. N., Dahlstrom, W. G., Graham, J. R., Tellegen, Y. S., \& Kaemmer, B. (1989). Minnesota Multiphasic Personality Inventory-2, User's Guide, the Minnesota Report: Adult Clinical System. National Computer Systems.

Cartwright, D. (2001). The role of psychopathology and personality in rage-type homicide: A review. South African Journal of Psychology, 31(3), 12-19. https://doi.org/10.1177/008124630103100302

Chopin, J., Caneppele, S., \& Beauregard, E. (2020). An Analysis of Mobility Patterns in Sexual Homicide. Homicide Studies, 24(2), 178-202. https://doi.org/10.1177/1088767919884601

Cline, M. (2015). Psychopathology and Crime Causation : Insanity or Excuse ? 1(1).

Culhane, S. E., Walker, S., \& Gray, M. J. (2014). MMPI-2 Characteristics of Male Serial Murderers. Applied Psychology in Criminal Justice, 10(1), 21-45.

Dariyo, A. (2013). Mengapa Seseorang Mau Menjadi Pembunuh. Penelitian Psikologi, 4(1), 
Rahel Gloria Natalia Abel \& Setyani Alfinuha | Karakteristik Kepribadian

$10-20$.

jurnalpsikologi.uinsby.ac.id/index.php/jurnalpsikologi/article/view/10/3\%0Ao

De Zulueta, F. (2006). From Pain to Violence: The Traumatic Roots of Destructiveness. In John Wiley \& Sons. https://doi.org/10.1002/9780470713167

Declercq, F., \& Audenaert, K. (2011). A case of mass murder: Personality disorder, psychopathology and violence mode. Aggression and Violent Behavior, 16(2), 135143. https://doi.org/10.1016/j.avb.2011.02.001

Grossman, D. (2009). On killing, the psychological cost of learning to kill in war and society. Little Brown Company.

Häkkänen, H. (2010). Murder by Manual Profiling Crime Scene Behaviors and Offender Characteristics. Criminal Profiling, 73-87. http://eknygos.lsmuni.lt/springer/605/73-87.pdf

Hathaway, S. R., \& McKinley, J. C. (1943). The Minnesota Multiphasic Personality Inventory. University of Minnesota Press.

Helfgott, J. B. (2008). Criminal behavior: Theories, thypologies, and criminal justice. SAGE Publications.

Howitt, D. (2009). Introduction to forensic and criminal psychology. Pearson Education.

Hughes, N. S., Macaulay, A. M., \& Crichton, J. H. M. (2012). Kitchen knives and homicide by mentally disordered offenders: a systematic analysis of homicide inquiries in England 1994-2010. Journal of Forensic Psychiatry and Psychology, 23(5-6), 559570. https://doi.org/10.1080/14789949.2012.721132

Ioannou, M., Canter, D., Youngs, D., \& Synnott, J. (2015). Offenders' Crime Narratives Across Different Types of Crimes. Journal of Forensic Psychology Practice, 15(5), 383-400. https://doi.org/10.1080/15228932.2015.1065620

Knight, Z. G. (2007). Sexually motivated serial killers and the psychology of aggression and "evil" within a contemporary psychoanalytical perspective. Journal of Sexual Aggression, 13(1), 21-35. https://doi.org/10.1080/13552600701365597

Krahe, B. (2005). No TitlePerilaku agresif: Buku panduan psikologi sosial. Alih Bahasa: Helly P. Soetjipto dan Sri Mulyantini Soetjipto. PT. Pustaka Pelajar.

Krakowski, M., Volavka, J., \& Brizer, D. (1986). Psychopathology and violence: A review of literature. Comprehensive Psychiatry, 27(2), 131-148. https://doi.org/10.1016/0010-440X(86)90022-2

Masykur, A. M., \& Subandi, S. (2018). Perjalanan Menuju Puncak Agresi: Studi Fenomenologi-Forensik Pada Remaja Pelaku Pembunuhan. Jurnal Psikologi, 17(1), 31. https://doi.org/10.14710/jp.17.1.31-43 
Meehan, J., Flynn, S., Hunt, I. M., Robinson, J., Bickley, H., Parsons, R., Amos, T., Kapur, N., Appleby, L., \& Shaw, J. (2006). Perpetrators of Homicide With Schizophrenia: A National Clinical Survey in England and Wales. Psychiatric Services, 57(11), 16481651. https://doi.org/10.1176/appi.ps.57.11.1648

Oram, S., Flynn, S. M., Shaw, J., Appleby, L., \& Howard, L. M. (2013). Mental illness and domestic homicide: A population-based descriptive study. Psychiatric Services, 64(10), 1006-1011. https://doi.org/10.1176/appi.ps.201200484

Putra, M. F. S., Susilo, B., \& Puspitaningrum, D. (2016). Sistem Pakar Minesota Multiphasic Personality Inventory ( Tes Mmpi ) Dengan Algoritma Certainty Factor Psikopatologi Seseorang ( Studi Kasus Rsjko Soeprapto ). Jurnal Rekursif, 4, 130139.

Rosenfeld, R. (2019). The 2014-2016 Homicide Rise: Introduction to the Special Issue. Homicide Studies, 23(3), 199-201. https://doi.org/10.1177/1088767919850230

Steury, E. H., \& Choinski, M. (1995). "Normal” crimes and mental disorder. A two-group comparison of deadly and dangerous felonies. International Journal of Law and Psychiatry, 18(2), 183-207. https://doi.org/10.1016/0160-2527(95)00005-3

Sturup, J. (2018). Comparing serial homicides to single homicides: A study of prevalence, offender, and offence characteristics in Sweden. Journal of Investigative Psychology and Offender Profiling, 15(2), 75-89. https://doi.org/10.1002/jip.1500

Trojan, C., \& Salfati, C. G. (2011). Linking criminal history to crime scene behavior in single-victim and serial homicide: Implications for offender profiling research. Homicide Studies, 15(1), 3-31. https://doi.org/10.1177/1088767910397281

Wong, J. S., \& Harraway, V. (2019). Media Presentation of Homicide: Examining Characteristics of Sensationalism and Fear of Victimization and Their Relation to Newspaper Article Prominence. Homicide Studies. https://doi.org/10.1177/1088767919896391

Yeni, F., Putra, A. A., \& Rahayuningsih, T. (2017). Pemrofilan kriminal pelaku pembunuhan berencana. Psychopolytan (Jurnal Psikologi), 1(1), 1-10. 